\title{
A Comparison between Conventional Tilled and Bicropped Winter Wheat Grown in Monoculture over Four Years
}

\author{
J. M. Finnan ${ }^{1}$, J. I. Burke ${ }^{2} \&$ T. M. Thomas ${ }^{1}$ \\ ${ }^{1}$ Oak Park Research Centre, Carlow, Republic of Ireland \\ ${ }^{2}$ School of Agriculture and Food Science, University College Dublin, Belfield, Dublin \\ Correspondence: J. M. Finnan, Teagasc Crops Research Centre, Oak Park, Carlow, Republic of Ireland. Tel: \\ 353-5991-70253. E-mail: john.finnan@teagasc.ie
}

\author{
Received: September 29, 2015 Accepted: October 21, 2015 Online Published: November 2, 2015 \\ doi:10.5539/sar.v5n1p24 \\ URL: http://dx.doi.org/10.5539/sar.v5n1p24
}

\begin{abstract}
A four year experiment was conducted at a site in the south-east of Ireland in which medium and high input conventional winter wheat production systems were compared to no input and low input systems in which winter wheat was direct drilled into an understory of white clover. Whole crop and grain yields from all systems were strongly related to external input levels, yields from bicropped treatments were poor. Nitrogen uptake and grain yields from the conventional treatments declined during the course of the study whereas nitrogen uptake and yields from bicropped treatments were more stable. Fertiliser $\mathrm{N}$ application significantly depressed biological production efficiency and altered biomass partitioning. The proportion of biomass partitioned to the stem decreased with fertiliser $\mathrm{N}$, differences between treatments persisted until final harvest. Although the clover sward was still present in the fourth year, this component of the bicrop was gradually replaced by weeds as the experiment progressed in spite of several attempts to control weeds. It is suggested that further research is needed to identify a clover management strategy which ensures the persistence of the white clover sward and allows it to enrich soil fertility in such a way as to be of benefit to the accompanying wheat crop.
\end{abstract}

Keywords: Winter wheat, bicropping, nitrogen uptake, harvest index, biological production efficiency, nitrogen utilization efficiency

\section{Introduction}

It has long been established that increased production and forage quality will result when legumes are grown along with grasses in pastures (Haystead \& Marriott, 1978; Simpson, 1965; Whitney, 1977). In addition to increased production, a concurrent increase in soil nitrogen $(\mathrm{N})$ occurs and annual amounts in excess of $100 \mathrm{Kg}$ $\mathrm{N} \mathrm{ha}^{-1}$ can be accumulated (Clement \& Williams, 1967). Legumes are often included as a component in crop rotations because of their beneficial effects on soil fertility. Succeeding crops benefit from enhanced availability of $\mathrm{N}$ after residual legume shoots and roots have decomposed. This source of organic $\mathrm{N}$ can be made available to succeeding crops after ploughing and arable cropping and its availablitity reduces the requirement for fertiliser $\mathrm{N}$ (Clement \& Williams, 1967). Additionally, the inclusion of a legume in a rotation leads to increases in the levels of soil organic matter as well as to improvements in soil structure (Ladd et al., 1983). The practise of crop rotation as well as interest in the use of legumes as sources of $\mathrm{N}$ declined in developed regions of the world when cheap forms of inorganic N fertiliser became available (Groya \& Sheaffer, 1985). In contrast, mixed cropping and intercropping systems including legumes have been and continue to be used in countries where $\mathrm{N}$ fertilizers are difficult to obtain (Remison, 1978; Martin \& Snaydon, 1982).

The achievement of high grain yields in winter wheat crops is dependent on the availability of nitrogen $(\mathrm{N})$, an essential element involved in all of the plants metabolic processes. Substantial increases in grain yields have been made possible by the availability of $\mathrm{N}$ fertiliser (Bell et al., 1995). However, $\mathrm{N}$ is costly to produce and is easily dissipated in the environment if applied incorrectly, a sizable portion of applied $\mathrm{N}$ is lost by leaching and denitrification (Huber et al., 1977). Thus, both environmental and economic considerations have driven a quest to reduce inputs of $\mathrm{N}$ fertiliser both by developing management practises more responsive to the physiological needs of crops and by increasing the efficiency with which absorbed nitrogen is used to produce grain. Cereal-legume intercropping systems offer one possible way of minimising inputs of fertiliser $\mathrm{N}$ by utilizing the legume component to improve soil fertility (Ofori \& Stern, 1987). Brophy et al. (1987) demonstrated that N 
transfer was possible between a legume and an associated non-legume. Simultaneous seeding of legumes and small grains has provided mixed results (Stewart et al., 1980; Brandt et al., 1989). However, the development of direct drills has enabled cereal crops to be drilled into an already established clover understory. Williams and Hayes (1991) showed that spring cereals could be direct drilled into a clover understory once clover growth had been suppressed. Jones (1992) drilled spring barley, spring oats and winter barley into an understory of white clover and found that whole crop silage and grain yields were similar to those obtained by traditional methods. Jones and Clements (1993) successfully grew winter wheat in a white clover understory over several years although yields were low. White and Scott (1991) examined the effects of small grain species, living mulch species and topdress $\mathrm{N}$ in a two year study in which winter cereals were direct drilled into living mulches. Of the living mulches tested, red and white clovers showed the greatest potential to produce dry matter with little interference to the cereals and appeared to contribute nitrogen to rye. Schmidt et al. (2003) showed that the presence of a clover understory had a beneficial effect on earthworm populations, previous work had shown that earthworms increased the biomass and $\mathrm{N}$ uptake of wheat (Schmidt \& Curry, 1999).

Previous experiments had shown that cereals could be successfully drilled into a clover understory, that the clover understory could survive several cereal crops and that the yield of cereal crops drilled into a clover understory was comparable to those of conventionally sown cereal crops. In this study winter wheat-clover bicropping sytems which received either no inputs of $\mathrm{N}$ fertiliser and plant protection chemicals or low inputs of these additives were compared to medium and high input commercially used systems in which winter wheat was sown into tilled soil. The objective of the study was to examine the possibility of a low input production system for winter wheat which would utilise biologically fixed $\mathrm{N}$ and which would not need high inputs of fertiliser $\mathrm{N}$ or plant protection chemicals.

\section{Materials and Methods}

The field investigations were carried out in one experimental field at Oak Park Research Centre, Carlow, Republic of Ireland, Latitude $52^{0} 51^{\prime} 12^{\prime \prime} \mathrm{N}$ and Longitude $6^{0} 54^{\prime} 15^{\prime \prime} \mathrm{W}$. The soil is a free draining medium-heavy textured limestone soil with $3 \%$ organic carbon content. The field, which had been intensively cropped for over 20 years, was left fallow during 1993 following a crop of spring barley harvested in August 1992. All plots received $37 \mathrm{Kg} \mathrm{P} / \mathrm{ha}$ and $74 \mathrm{Kg} \mathrm{K} / \mathrm{ha}$ during each year of the study. Additionally, the experimental area received $70 \mathrm{Kg} \mathrm{K} / \mathrm{ha}$ in March 1995 as soil analysis had indicated the level of this element to be particularly low.

\subsection{Treatments}

The trial layout was a randomised complete block with four replications, each plot measuring 60 metres long and 10 metres wide. The same plots were used for each treatment in all four years of the study. The four treatments were replicated in each block. These were; winter wheat drilled into a white clover sward, no fertiliser nitrogen, no plant protection chemicals (Bicropped, zero); winter wheat drilled into a white clover sward, $50 \mathrm{Kg} \mathrm{N} / \mathrm{ha}$, low input of plant protection chemicals (Bicropped, low); winter wheat sown into a conventional ploughed seedbed, $160 \mathrm{Kg} \mathrm{N} / \mathrm{ha}$, low input of plant protection chemicals (Conventional, medium); winter wheat sown into a conventional ploughed seed bed, $200 \mathrm{Kg} \mathrm{N} / \mathrm{ha}$, high input of plant protection chemicals (Conventional, high). Further details are provided in Table 1.

Table 1. Details of treatments

\begin{tabular}{|lllll|}
\hline Treatment & $\begin{array}{l}\text { Bicropped, } \\
\text { Zero }\end{array}$ & Bicropped, Low & Conventional, medium & Conventional, high \\
Nitrogen & $0 \mathrm{Kg} / \mathrm{ha}$ & $50 \mathrm{Kg} / \mathrm{ha}$ & $160 \mathrm{Kg} / \mathrm{ha}$ & $200 \mathrm{Kg} / \mathrm{ha}$ \\
Growth & & & Half Rate Growth & Full Rate Growth \\
Regulator & & Regulator & Regulator \\
Herbicide & & Half Rate Autumn & Full Rate Autumn \\
& & Herbicide & Herbicide \\
Insecticide & & Full Rate pre-harvest & Full Rate Autumn \\
& & Insecticide & Insecticide \\
& & & Full Rate pre-harvest \\
& & & Insecticide \\
Fungicide & $2 *$ Half Rate Fungicide & $2 *$ Half Rate Fungicide & $3 *$ Full Rate Fungicide \\
& applications & applications & aplications \\
\hline
\end{tabular}


Towards the end of June 1996, a large number of aphids were found on bicropped plots. A selective insecticide (perimicarb) was used to control this problem. Grass weeds (Poa annua, Poa trivialis, Agrostis stolinifera, Agrostis tenuis) became increasingly problematical in the bicropped plots as the experiment progressed and a number of attempts were made to eradicate this problem. Avadex granules (active ingredient tri-allate) were applied in November 1996, bicropped crops were sprayed with Fusilade (active ingredient fluazifop-P-butyl) in September 1997 and Topik (active ingredient clodinafop-propargyl) was sprayed on bicropped treatments in Febuary 1998. In March 1998, it was found necessary to spray bicropped plots with Benazolin to control Galium aparine. It was still found necessary to spray bicropped plots with glyphosate in August 1998 to facilitate harvesting in spite of all attempts to control weeds.

The period after sowing was very wet in October 1997 and slug numbers increased dramatically. Consequently, methaldehyde pellets were broadcast on all plots on $17^{\text {th }}$ October, methiocarb pellets were broadcast on $23^{\text {rd }}$ October.

\subsection{Clover Establishment}

White clover (cv. Donna) was sown into the plots of the bicropped treatments on $28^{\text {th }}$ April 1994. The clover was drilled at a seeding rate of $9.0 \mathrm{Kg} / \mathrm{ha}$ in rows $15 \mathrm{cms}$ apart. A herbicide mixture containing MCPB, MCPA and benazolin was sprayed on 14th June to control annual broad leaved weeds. The clover was cut, wilted for three days and baled as silage during September 1994. Clover regrowth was grazed by sheep.

\subsection{Wheat Establishment}

In each year of the experiment, clover was cut and removed from the bicropped plots before wheat was sown. Wheat was sown into the bicropped plots using a Hunter rotaseeder drill at a row spacing of $22.8 \mathrm{cms}$. This drill uses a set of powered rotating blades to till a shallow $5 \mathrm{~cm}$ wide strip of soil. It was found necessary to drag a heavy chain behind the drill to ensure sufficient coverage of the seed.

Conventional treatments were ploughed and tilled before wheat was sown using a seed drill at a row spacing of $12 \mathrm{cms}$. All treatments were sown at a seeding rate of $200 \mathrm{Kg} / \mathrm{ha}$ in the 1994/95 and 1995/96 growing seasons. All treatments were sown at a seeding rate of $170 \mathrm{Kg} / \mathrm{ha}$ in the 1996/97 and 1997/98 growing seasons. Sowing dates are given in Table 2.

Table 2. Dates of Sowing and harvest

\begin{tabular}{llcc}
\hline & Sowing Date & Whole Crop Harvest Date & Final Harvest Date \\
\hline $1994 / 95$ & $11 / 10 / 94$ & $10 / 7 / 95$ & $4 / 8 / 95$ \\
$1995 / 96$ & $18 / 10 / 95$ & $23 / 7 / 96$ & $16 / 8 / 96$ \\
$1996 / 97$ & $9-10 / 10 / 96$ & $15 / 7 / 97$ & $15 / 8 / 97$ \\
$1997 / 98$ & $8-9 / 10 / 97$ & - & $31 / 8 / 98$ \\
\hline
\end{tabular}

\subsection{Cereal Seedling Establishment}

The establishment of wheat plants was determined during the spring after sowing. In this assessment, two adjacent $0.5 \mathrm{~m}$ row lengths were dug up at three random locations per plot and the number of plants were counted.

\subsection{Measurements of Soil N}

On $25^{\text {th }}$ November 1998, a soil corer was used to take soil samples from each plot. Four soil cores were taken from each plot, each core was divided into a $0-15 \mathrm{~cm}$ fraction as well as a $15-30 \mathrm{~cm}$ fraction. Ammonium nitrogen and nitrate nitrogen was determined in both fractions.

\subsection{Intermediate Harvests}

Twenty plants were sampled at random from each plot at 2-3 week intervals from spring until final harvest in 1995, 1996 and 1997. The roots were removed before the plants were divided into leaves, stems and ears. The individual plant parts were dried to constant weight at 70 degrees centigrade. The dried plant parts were weighed before being ground. Percentage $\mathrm{N}$ was determined on the ground material using a LECO FP-228 Nitrogen determinator (LECO Corporation, St Joseph, Michigan, U.S.A.). Biological production efficiency was determined at each of the individual harvests as accumulated biomass/ accumulated nitrogen. 


\subsection{Whole Crop Silage}

Whole crop silage was harvested in 1995, 1996 and in 1997. A swath $\left(1.25 \mathrm{~m}^{*} 10 \mathrm{~m}\right)$ was cut from each plot approximately one month before final harvest when the wheat was at dough stage. The total freshweight of the freshly harvested material was determined. Sub-samples were taken to determine botanical composition and dry matter content.

\subsection{Final Harvest}

Three $0.5 \mathrm{~m}^{2}$ quadrats were harvested from each plot immediately before final harvest. The roots were removed from the plants before the ears were seperated, from the straw and threshed into grain and chaff, all plant parts were then dried. Harvest index was calculated as grain weight divided by (grain weight+weight of chaff+weight of straw). The percentage of nitrogen in the grain was determined using a LECO FP-228 Nitrogen determinator (LECO Corporation, St Joseph, Michigan, U.S.A.). Nitrogen harvest index was determined as grain nitrogen / total plant $\mathrm{N}$ determined at the last intermediate harvest . Nitrogen utilization efficiency (Moll et al., 1982) was calculated as grain produced per unit of whole plant nitrogen. The total uptake of $\mathrm{N}$ in 1998 was determined using these three quadrats of plants harvested immediately before final harvest. After drying, the individual plant parts were ground before percentage $\mathrm{N}$ was determined using a LECO $\mathrm{N}$ determinator.

Grain yield was quantified by harvesting two $60 \mathrm{~m}$ strips from each plot using a plot combine. A sub-sample of the grain harvested from each plot was taken for analysis of percentage moisture. After harvest, straw was baled and removed from each plot.

\subsection{Statistics}

In the case of soil nutrient levels and plant establishment, two way analysis of variance was used to determine differences between treatments. For all other parameters, multiway analysis of variance was used to determine the effect of treatment, time and to test for interaction. Data was analysed using the GLM procedure of the Minitab statistical package (Minitab Inc., 3081 Enterprise Drive, PA 16801-3008).

\section{Results}

\subsection{Soil Nutrient Status}

The results of measurements of soil mineral $\mathrm{N}$ content are shown in Table 4. Treatments had no effect on soil ammonium nitrogen. Levels of nitrate in the $15-30 \mathrm{~cm}$ fraction were higher in bicropped treatments although the effect was not statistically significant. There were significantly higher levels $(p<0.05)$ of nitrate in bicropped treatments at $15-30 \mathrm{cms}$ depth.

\subsection{Establishment of Wheat Plants}

Plant establishment was lower in the bicropped treatments in comparison to the conventional treatments in all four years of the study (Table 3). Both conventional treatments had significantly more plants per $\mathrm{m}^{2}(\mathrm{p}>0.01)$ compared to both bicropped treatments in 1995 . There were no significant differences between treatments in 1996 although conventional treatments did have more plants $/ \mathrm{m}^{2}$ compared to bicropped treatments. In 1997, the high input conventional treatment had significantly $(\mathrm{p}<0.05-\mathrm{p}<0.01)$ more plants $/ \mathrm{m}^{2}$ compared to both bicropped treatments and the low input conventional treatment had significantly more plants $/ \mathrm{m}^{2}(\mathrm{p}<0.05)$ compared to the low input bicropped treatment. The low input conventional treatment had significantly more plants $/ \mathrm{m}^{2} \quad(\mathrm{p}>0.05)$ compared to the high input bicropped treatment in 1998. There were no significant differences in plant establishment between the two bicropped treatments or between the two conventional treatments.

Table 3. Wheat plant establishment 1994-1998

\begin{tabular}{lcccc}
\hline & $8 / 3 / 95$ & $3 / 3 / 96$ & $2 / 4 / 97$ & $20 / 2 / 98$ \\
\hline Bicropped, zero & 348.1 & 332.1 & 301.6 & 245.6 \\
Bicropped, low & 344.8 & 327.0 & 323.4 & 207.8 \\
Conventional, medium & 434.0 & 373.7 & 357.7 & 284.9 \\
Conventional, high & 451.4 & 368.9 & 380.6 & 250.9 \\
s.e.d (9 d.f) & 23.28 & 21.7 & 23.6 & 21.5 \\
\hline
\end{tabular}


Table 4. Soil measurements of nitrate and ammonium nitrogen ( $\mathrm{mg} / \mathrm{Kg}$ dry soil)

\begin{tabular}{lllll}
\hline & $\begin{array}{l}0-15 \mathrm{cms} \\
\text { nitrate nitrogen }\end{array}$ & $\begin{array}{l}15-30 \mathrm{cms} \\
\text { nitrate } \\
\text { nitrogen }\end{array}$ & $\begin{array}{l}0-15 \mathrm{cms} \\
\text { ammonium } \\
\text { nitrogen }\end{array}$ & $\begin{array}{l}15-30 \mathrm{cms} \\
\text { ammonium } \\
\text { nitrogen }\end{array}$ \\
\hline Bicropped, zero & 7.7 & 7.3 & 5.9 & 5.0 \\
Bicropped, low & 7.7 & 7.9 & 5.1 & 4.9 \\
Conventional, medium & 4.3 & 3.8 & 5.9 & 4.6 \\
Conventional, High & 4.2 & 3.9 & 6.4 & 4.7 \\
s.e.d & 3.1 & 1.3 & 0.6 & 0.3 \\
$(9$ d.f.) & & & \\
\hline
\end{tabular}

Table 5. Treatment effect on winter wheat yield, nitrogen accumulation, biomass and nitrogen distribution and treatment effects on whole crop silage. $*, * *, * * *, * * * *$ significant at the $0.05,0.01,0.001,0.0001$ level respectively, n.s. not significant

\begin{tabular}{|c|c|c|c|c|c|c|c|c|c|c|}
\hline Year & Treatment & $\begin{array}{l}\text { Grain } \\
\text { Yield } \\
\text { (t/ha@ } \\
15 \% \mathrm{~m})\end{array}$ & Ears/m2 & Grains/ear & $\begin{array}{l}1000 \\
\text { gw } \\
(\mathrm{g})\end{array}$ & $\begin{array}{l}\text { Wheat } \\
\text { Biomass } \\
(\mathrm{t} / \mathrm{ha})\end{array}$ & $\begin{array}{l}\text { Harvest } \\
\text { Index }\end{array}$ & $\begin{array}{l}\text { Nitrogen } \\
\text { Uptake } \\
(\mathrm{Kg} / \mathrm{ha})\end{array}$ & $\begin{array}{l}\text { Nitrogen } \\
\text { Utilization } \\
\text { efficiency }\end{array}$ & $\begin{array}{l}\text { Whole Crop } \\
\text { Silage Yield } \\
\text { (t/ha D.M) }\end{array}$ \\
\hline \multirow[t]{4}{*}{1995} & Bicropped, Zero & 1.6 & 275.4 & 13.8 & 41.2 & 8.4 & 21.2 & 64.2 & 20.8 & 9.3 \\
\hline & Bicropped, Low & 3.1 & 282.4 & 24.0 & 44.2 & 12.4 & 24.5 & 89.5 & 30.0 & 13.0 \\
\hline & $\begin{array}{l}\text { Conventional, } \\
\text { Medium }\end{array}$ & 8.6 & 453.4 & 40.2 & 46.1 & 16.9 & 34.0 & 170.0 & 43.6 & 20.7 \\
\hline & $\begin{array}{l}\text { Conventional, } \\
\text { High }\end{array}$ & 10.1 & 540.0 & 39.2 & 46.4 & 20.7 & 39.2 & 205.2 & 43.1 & 21.9 \\
\hline \multirow[t]{4}{*}{1996} & Bicropped, Zero & 1.5 & 289.3 & 14.7 & 36.8 & 6.1 & 28.2 & 43.5 & 26.7 & 7.6 \\
\hline & Bicropped, Low & 2.4 & 316.6 & 20.4 & 39.0 & 9.7 & 30.7 & 64.7 & 31.3 & 11.3 \\
\hline & $\begin{array}{l}\text { Conventional, } \\
\text { Medium }\end{array}$ & 8.2 & 496.0 & 43.4 & 39.6 & 20.0 & 41.5 & 182.0 & 39.1 & 15.7 \\
\hline & $\begin{array}{l}\text { Conventional, } \\
\text { High }\end{array}$ & 9.8 & 571.3 & 43.4 & 40.8 & 22.8 & 45.0 & 240.0 & 34.5 & 17.9 \\
\hline \multirow[t]{4}{*}{1997} & Bicropped, Zero & 1.6 & 260.3 & 16.8 & 40.3 & 6.7 & 29.0 & 59.3 & 22.6 & 8.9 \\
\hline & Bicropped, Low & 2.6 & 252.6 & 26.8 & 42.1 & 11.0 & 33.5 & 102.2 & 22.2 & 10.3 \\
\hline & $\begin{array}{l}\text { Conventional, } \\
\text { Medium }\end{array}$ & 6.0 & 389.0 & 45.7 & 35.4 & 17.2 & 37.7 & 175.1 & 29.7 & 12.9 \\
\hline & $\begin{array}{l}\text { Conventional, } \\
\text { High }\end{array}$ & 7.3 & 411.7 & 49.1 & 38.8 & 18.1 & 40.2 & 203.6 & 30.8 & 15.1 \\
\hline \multirow[t]{7}{*}{1998} & Bicropped, Zero & 1.5 & 296.6 & 13.0 & 40.9 & 6.5 & 29.2 & 55.3 & 23.1 & \\
\hline & Bicropped, Low & 2.5 & 328.6 & 19.4 & 42.1 & 9.7 & 31.5 & 86.6 & 24.5 & \\
\hline & $\begin{array}{l}\text { Conventional, } \\
\text { Medium }\end{array}$ & 6.3 & 406.3 & 39.9 & 39.9 & 15.6 & 38.2 & 162.5 & 32.9 & \\
\hline & $\begin{array}{l}\text { Conventional, } \\
\text { High }\end{array}$ & 7.4 & 402.3 & 44.6 & 44.6 & 15.9 & 40.2 & 194.1 & 32.7 & \\
\hline & Year (3 d.f.) & $* * * *$ & $* * * *$ & $* * * *$ & $* * * *$ & $* * * *$ & $* * * *$ & n.s. & $* * * *$ & $* * * *$ (2 d.f.) \\
\hline & Treat (3 d.f.) & $* * * *$ & $* * * *$ & $* * * *$ & $* * * *$ & $* * * *$ & $* * * *$ & $* * * *$ & $* * * *$ & $* * * *$ (3 d.f.) \\
\hline & $\begin{array}{l}\text { Year * Treat ( } 9 \\
\text { d.f.) }\end{array}$ & $* * * *$ & $* * * *$ & n.s. & $* * * *$ & $* * * *$ & $* * * *$ & $* *$ & n.s. & $* * * *$ (6 d.f.) \\
\hline
\end{tabular}




\subsection{Whole Crop Silage}

Whole crop silage yields were closely related to input levels, there were statistically significant treatment effect during the experiment $(\mathrm{p}<0.0001$, Table 5). Whole crop silage yield from each treatment declined during the three years (significant time effect $\mathrm{p}<0.0001$, Figure 1). The rate of decrease in silage yield from year to year was greatest in the conventional treatments, there was a statistically significant interaction between year and treatment $(\mathrm{p}<0.0001)$. The rate of decline in whole crop silage yields was ameliorated in bicropped treatments as weed yields increased from year to year almost compensating for the decrease in wheat and clover yields.



Figure 1. Trends in whole crop silage harvest 1995-1997. Yields ( $t /$ ha dry matter) of weeds, clover, winter wheat

The clover understory was not threatened to any great extent by either biotic orabiotic factors during the course of the study. Although the clover sward was still present during the fourth year, it's extent had been dramatically reduced due to competition from weeds (Figure 1). In effect, the clover sward was gradually replaced during the course of the study by a crop of weeds. Several attempts were made to control the spread of weeds by different chemical means. These attempts were not successful. The most problematic weeds were grass weeds (Poa annua, Poa trivialis, Agrostis stolinifera, Agrostis tenuis) and Galium aparine.

\subsection{Wheat Yield}

Grain yields and total biomass yields from wheat were strongly related to input levels during the experiment $(\mathrm{p}<0.0001$, Table 5). Yields of all treatments declined during the course of the study (time effect $\mathrm{p}<0.0001$ ). There was also a significant time by treatment interaction $(p<0.0001)$, wheat yields from conventional treatments declined during the course of the study whereas yields from bicropped treatments were more stable. The high input bicropped treatment outyielded the low input bicropped treatment in all four years of the study.

\subsection{Nitrogen Uptake}

Nitrogen uptake in 1995, 1996 and 1997 is shown in Figure 2 as an index of nitrogen nutrition. The addition of fertiliser nitrogen resulted in dramatic increases in nitrogen uptake by the wheat plants. The total amount of nitrogen accumulated by each treatment prior to final harvest in each of the four years of the study is shown in Table 5. Nitrogen uptake increased with input level $(\mathrm{p}<0.0001)$ but there was a significant $(\mathrm{p}<0.01)$ interaction 
between time and treatment during the course of the study. Nitrogen uptake by the conventional treatments decreased during the course of the study whereas nitrogen uptake by the bicropped treatments was more stable.


Figure 2. Nitrogen accumulation by winter wheat in the 1995, 1996 and 1997 growing seasons for the bicropped zero (diamonds), bicropped low (squares), conventional medium (triangles) and conventional high (circles) treatments. Arrows show the timings of fertilizer applications

\subsection{Partitioning of Biomass and Nitrogen}

Nitrogen application altered biomass partitioning. Less biomass was concentrated in the stem and more in the leaf as nitrogen application increased (Figures 3 and 4). Supply of fertiliser nitrogen suppressed biological production efficiency (BPE), the biomass produced per unit of nitrogen absorbed (Figure 4). The reduction in 
BPE was proportional to the level of fertiliser applied. Application of the first split of nitrogen (50 Kg N for Bicropped low, $70 \mathrm{Kg} \mathrm{N}$ for conventional treatments) resulted in an initial reduction in BPE in 1996 and 1997. The second split of nitrogen $(90 \mathrm{Kg} \mathrm{N}$ for conventional medium, $130 \mathrm{Kg} \mathrm{N}$ for conventional high) resulted in a further suppression of BPE proportional to the level of nitrogen applied. The first intermediate harvest in 1995 took place after the second split of nitrogen had been applied, differences in BPE were already apparent at this stage, the parameter decreasing with quantity of applied nitrogen. Biological production efficiencies at the end of each growing season are shown in Table 5. Biological production efficiencies decreased with time in all treatments $(\mathrm{p}<0.0001)$ and there was a statistically significant treatment effect $(\mathrm{p}<0.0001)$.
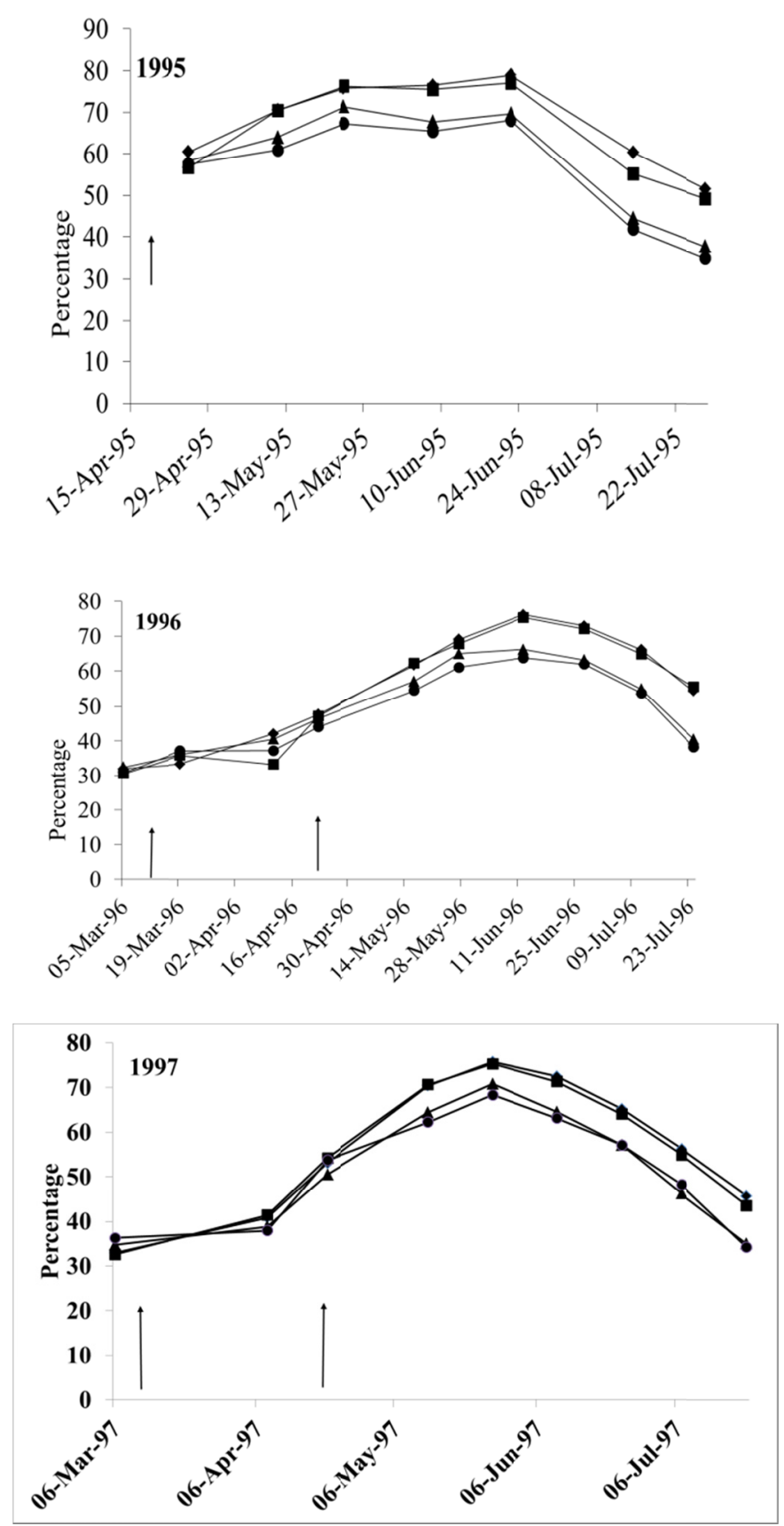

Figure 3. Winter wheat stem dry matter as a proportion of total dry matter. Trends 1995-1997 for the bicropped zero (diamonds), bicropped low (squares), conventional medium (triangles) and conventional high (circles) treatments. Arrows show the timings of fertilizer applications 

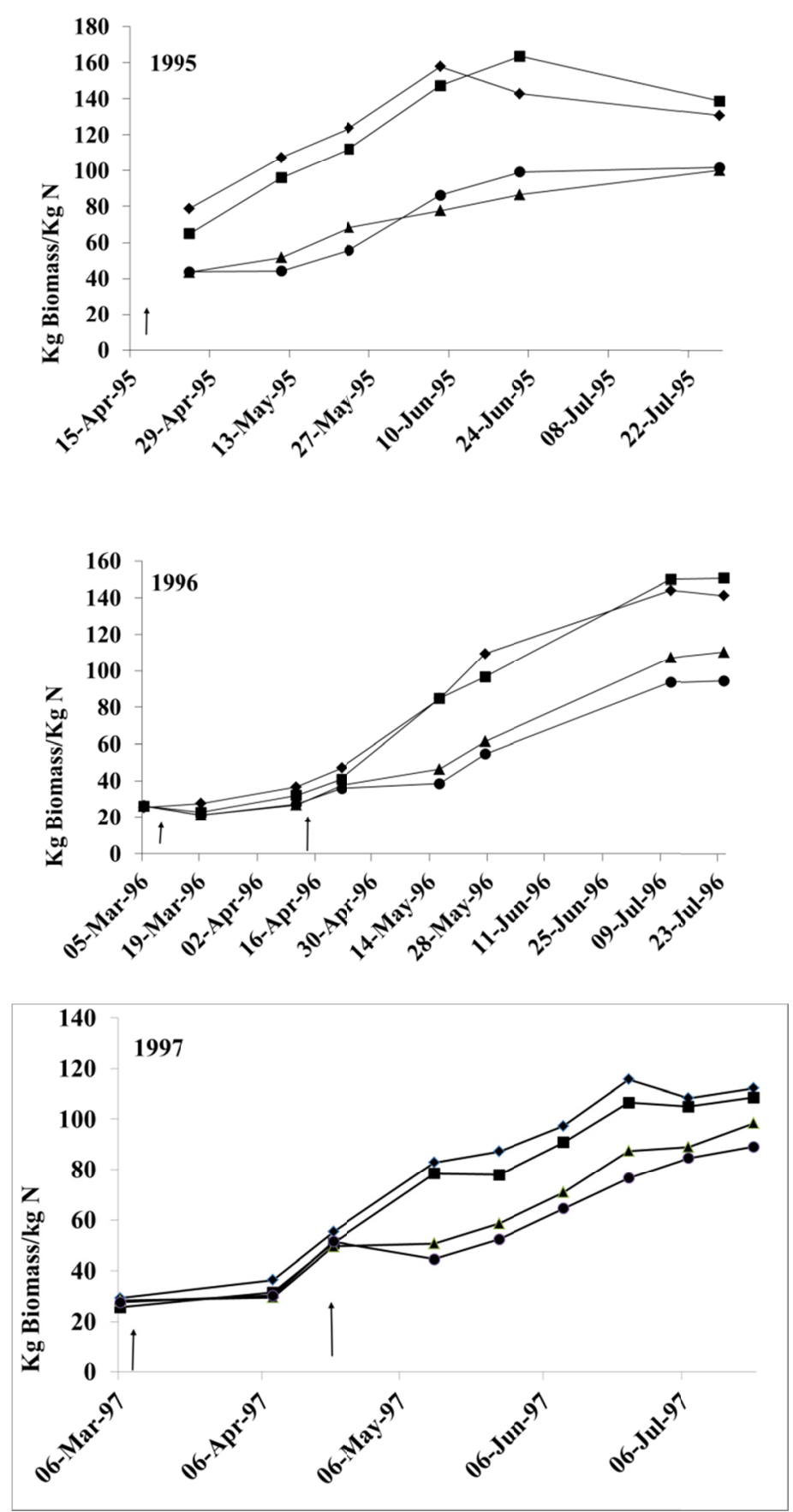

Figure 4. Trends in winter wheat biological production efficiency 1995-1997. Biological production efficiency represents biomass formed per unit of nitrogen. Data presented for the bicropped zero (diamonds), bicropped low (squares), conventional medium (triangles) and conventional high (circles) treatments. Arrows show the timings of fertilizer applications

Both harvest index and nitrogen harvest index increased with input level. Bicropped treatments were less efficient at allocating biomass and absorbed nitrogen to the growing grains (Table 5). The effect of treatment was highly significant on both harvest index and nitrogen harvest index $(p<0.0001)$. Harvest index and nitrogen harvest index increased in both bicopped treatments from year to year during the course of the experiment. However, this trend was not evident in the conventional treatments. Bicropped treatments were less efficient at converting absorbed $\mathrm{N}$ into grain yield throughout the experiment (Table 5), conventional treatments had higher nitrogen utilization efficiencies (NUE) in each of the four years of the study. The effect of treatment on NUE was statistically significant $(p<0.0001)$. 


\section{Discussion}

It is possible to establish successive winter wheat crops in a white clover understory although plant establishment was lower in direct drilled treatments. Jones (1992) also found reduced seedling emergence when cereal crops were direct drilled into a clover understory. Cornish and Lymbery (1987) have attributed reduced emergence in direct drilled crops to a combination of uneven sowing depth and to rougher seedbeds. In this study, the reduced plant establishment was at least partially attributable to the type of direct drill used to sow the bicropped wheat. Unless conditions were completely dry the powered rotating blades did not provide enough soil to cover the seeds sufficiently leaving seeds vulnerable to predation by birds. Additionally, the rotating blades had the effect of compacting the soil under the newly sown seeds providing a difficult environment for establishment to take place.

Nitrogen uptake by the bicropped winter wheat crops was low despite being more stable than that of conventional treatments which declined during the course of the study. Higher levels of nitrate nitrogen were found in the soils of bicropped treatments, a similar result was reported by Jones and Clements (1993). However, levels of $\mathrm{N}$ uptake in all treatments were similar to those reported in conventionally sown winter wheat nitrogen trials suggesting that the contribution from biologically fixed nitrogen was low (Powlson et al., 1986, Ortiz-Monasterio et al., 1997). Although this experiment was not a nitrogen trial per se, differences between treatments were largely a function of the level of nitrogen fertilization.

Differences in biomass accumulation between the two methods of cultivation were less than differences in grain yield because of differences in harvest index between treatments. Low harvest index was a contributory factor to the poor grain yields obtained from the bicropped treatments. Harvest index increased with the level of applied nitrogen irrespective of the method of cultivation. Spiertz and Ellen (1978) reported an increase in harvest index with nitrogen supply, Dreccer et al. (2000) reported a similar result. However, most studies have reported that harvest index decreases with applied N (Donald and Hamblin, 1976; Pearman et al., 1978; Ortiz-Monasterio et al., 1997; Le Gouis et al., 2000, Garner \& Dyke, 1969, Delogu et al., 1998). It is possible that high plant population density in the widely spaced rows of the bicropped treatments may have contributed to the substantial differences in harvest index between the two methods of cultivation. Puckridge and Donald (1967) reported a decrease in harvest index with increasing population density in wheat crops grown in Australia. Nitrogen harvest index also fell with increasing N, in contrast to the results of Spiertz and Ellen (1978), Le Gouis et al. (2000) and Dreccer et al. (2000). Poor harvest index in bicropped treatments ensured that nitrogen utilization efficiency was also low in these treatments and indeed the latter parameter followed the same trend as harvest index, increasing with added nitrogen. In contrast, a decrease in nitrogen utilization efficiency with added nitrogen has been reported by several authors (Sowers et al., 1994; Dhugga \& Waines, 1989, Ortiz-Monasterio et al., 1997, Delogu et al., 1998).

The addition of fertiliser $\mathrm{N}$ suppressed the efficiency of biological production and altered the partitioning of biomass so that more assimilate was partitioned into the leaf and less to the stem. Low biological production efficiencies at high levels of nitrogen have also been reported by Ortiz-Monasterio et al. (1997) and Le Gouis et al. (2000). Thus, the bicropped treatments with their low levels of added $\mathrm{N}$ were more efficient at converting absorbed $\mathrm{N}$ into biomass. However, although efficient at producing biomass, the bicropped treatments stored a higher percentage of their biomass in the stem compared to their conventional contempories. This pattern of biomass allocation continued up to final harvest. Bicropped treatments appeared unable to use the extra stem reserves to produce leaf laminae for photassimilate production or to use the same reserves for grain filling. The importance of stem reserves for grain filling particularly under conditions when current assimilation cannot meet the demands of developing grains has been demonstrated (Austin et al. 1977, 1980). In this experiment the efficiency of assimilate partitioning was a function of nitrogen supply and appears to have been determined around the time of the second split of $\mathrm{N}$.

Subsequent to this experiment, other studies have also reported lower grain yields in wheat-clover bicropping systems compared to conventional systems (Sarunaite et al., 2006; Thorsted et al., 2006a). Yield reductions have been attributed to the presence of clover, the negative effects of clover being stronger than the positive effects (Thorsted et al., 2006b). Thorsted et al. (2006a) attributed such yield reductions to interspecific competition for light and $\mathrm{N}$ during vegetative growth and for soil water during grain filling. Several studies have reported that grain yields in cereal/wheat bicropping systems can be substantially increased by legume defoliation by either herbicide (Bergkvist, 2003) or by the use of mechanical treatments (Thorsted et al., 2002; Thorsted et al., 2006c). Bergkvist (2003) concluded that competition from clover needs to be minimised when wheat is at the tillering stage in order to maximise grain yield while Thorsted et al., (2006c) reported that the largest yield increases were obtained when mechanical weed control was applied during stem elongation. Mechanical treatment increased $\mathrm{N}$ 
transfer between clover and wheat, possibly as a result of the fact that legume defoliation results in root and nodule death. However, the above studies in which wheat yields in wheat-clover bicropping systems were stimulated by legume defoliation were relatively short in duration ( 2 years) and the effects of such treatments on the longer term persistence of clover swards is, as yet, unknown.

The foremost practical problem encountered in this experiment was the control of weeds in bicropped treatments. Weed control is typically more problematical when crops are established by minimum cultivation compared to conventional tillage. Mouldboard ploughing in the latter method minimises the number of weed seeds that can germinate. Christian and Bacon (1990) reported that direct drilling increased populations of annual meadow grass (Poa annua) and rough stalked meadow grass (Poa trivialis). Ball et al. (1994) found that direct drilled plots of winter barley became infested with soft brome (Bromus mollis L.). Experiments in England have demonstrated that grass weeds can pose a significant threat when winter cereals are grown continuously using minimum cultivation (Wilson et al., 1989). There were several attempts in this study to control weed infestation using several herbicides, none of these attempts were successful. Weed control options were restricted by the need to choose a herbicide which had no detrimental effect on clover. The absence of suitable herbicides delayed the introduction of direct drilling for many years (Cannell and Hawes, 1994). Similarly, at present a clover-wheat intercrop is not sustainable over a number of years due to the lack of a suitable herbicide to control weeds in the clover component of the bicrop.

Higher levels of nitrate nitrogen found in the soil of bicropped treatments were not sufficient to be of benefit to the nitrogen economy of the bicropped wheat crops which had insufficient nitrogen available to them at the appropriate time to generate a sink for grain yield. Reducing the need for fertiliser nitrogen by providing wheat with a supply of biological nitrogen is a noble aspiration. However, further research is needed to identify a legume management strategy that could provide wheat with sufficient nitrogen at the appropriate time.

\section{Acknowledgements}

The co-operation and assistance of Peter Tiernan, Ivan Mitchell and Pat Prior is gratefully acknowledged. Additionally, the authors wish to thank the Commission of the European Communities for financial support.

\section{References}

Austin, R. B., Edrich, J. A., Ford, M. A. \& Blackwell, R. D. (1977). The fate of the dry matter, carbohydrates and $14 \mathrm{C}$ lost from the leaves and stems of wheat during grain filling. Annals of Botany, 41, 1309-1321.

Austin, R. B., Morgan, C. L., Ford, M. A., \& Blackwell, R. D. (1980). Contributions to grain yields from pre-anthesis assimilation in tall and dwarf barley phenotypes in two contrasting seasons. Annals of Botany, 45, 309-319.

Ball, B. C., Lang, R. W., Robertson, E. A. G., \& Franklin, M. F. (1994). Crop performance and soil conditions on imperfectly drained loams after 20-25 years of conventional tillage or direct drilling. Soil and Tillage Research, 31, 97-118. http://dx.doi.org/10.1016/0167-1987(94)90074-4

Bell, M. A., Fischer, R. A., \& Byerlee, S. K. (1995). Genetic and agronomic contributions to yield gains: a case study for wheat. Field and Crops Research, 44, 55-65. http://dx.doi.org/10.1016/0378-4290(95)00049-6

Bergkvist, G. (2003). Effect of white clover and nitrogen availability on the grain yield of winter wheat in a three season intercropping system. Acta Agriculturae Scandanavica, Section B. Soil and Plant Science, 53, 97-109. http://dx.doi.org/10.1080/09064710310011953

Brandt, J. E., Hons, F. M., \& Haby, V. A. (1989). Effects of subterranean clover interseeding on grain yield, yield components and nitrogen content of soft red winter wheat. Journal of Production Agriculture, 2(4), 347-351. http://dx.doi.org/10.2134/jpa1989.0347

Brophy, L. S., Heichel, G. H., \& Russelle, M. P. (1987). Nitrogen transfer from forage legumes to grass in a $\begin{array}{lllll}\text { systematic planting } & \text { design. } & \text { Crop } & \text { Science, } & 27,\end{array}$ http://dx.doi.org/10.2135/cropsci1987.0011183X002700040030x

Cannell, R. Q., \& Hawes, J. D. (1994). Trends in tillage practises in relation to sustainable crop production with special reference to temperate climates. Soil and Tillage Research, 30, 245-282. http://dx.doi.org/10.1016/0167-1987(94)90007-8

Christian, D., \& Bacon, E. T. B. (1990). A long term comparison of ploughing, tine cultivation and direct drilling on the growth and yield of winter cereals and oilseed rape on clayey and silty soils. Soil and Tillage Research, 18, 311-331. http://dx.doi.org/10.1016/0167-1987(90)90117-V 
Clement, C. R., \& Williams, T. E. (1967). Leys and organic matter. II. The accumulation of nitrogen in soils under different leys. Journal of Agricultural Science, Cambridge, 69, 133-138. http://dx.doi.org/10.1017/S0021859600016543

Cornish, P. S., \& Lymbery, J. R. (1987). Reduced early growth of direct drilled wheat in southern New South Wales: causes and consequences. Australian Journal of Experimental Agriculture, 27, 869-880. http://dx.doi.org/10.1071/EA9870869

Delogu, G., Cattivelli, L., Pecchioni, N., De Falcis, D., Maggiore, T., \& Stanca, M. (1998). Uptake and agronomic efficiency of nitrogen in winter barley and winter wheat. European Journal of Agronomy, 9, 11-20. http://dx.doi.org/10.1016/S1161-0301(98)00019-7

Dhugga, K. S., \& Waines, J. G. (1989). Analysis of nitrogen accumulation and use in bread and durum wheat. Crop Science, 29, 1232-1239. http://dx.doi.org/10.2135/cropsci1989.0011183X002900050029x

Donald, C. M., \& Hamblin, J. (1976). The biological yield and harvest index of cereals as agronomic and plant breeding criteria. Advances in Agrononomy, 28, 361-405. http://dx.doi.org/10.1016/S0065-2113(08)60559-3

Dreccer, M. F., Schapendonk, A. H. C. M., Slafer, G. A., \& Rabbinge, R. (2000). Comparative response of wheat and oilseed rape to nitrogen supply: absorption and utilisation efficiency of radiation and nitrogen during the reproductive stages determining yield. Plant and Soil, 220, 189-205. http://dx.doi.org/10.1023/A:1004757124939

Garner, H. V., \& Dyke, G. V. (1969). The Broadbalk Yields. Report of Rothamsted Experimental Station 1968, 2, 26-49.

Groya, F. L., \& Sheaffer, C. C. (1985). Nitrogen from forage legumes: harvest and tillage effects. Agronomy Journal, 77, 105-109. http://dx.doi.org/10.2134/agronj1985.00021962007700010025x

Haysteed, A., \& Marriott, C. (1978). Fixation and transfer of nitrogen in a clover-grass sward under hill conditions. Annals of Applied Biology, 88, 453-457. http://dx.doi.org/10.1111/j.1744-7348.1978.tb00740.x

Huber, D. M., Warren, H. L., Nelson, D. W., \& Tsai, C. Y. (1977). Nitrification inhibitors- new tools for food production. Bio-Science, 27, 523-529. http://dx.doi.org/10.2307/1297812

Jones, L. (1992). Preliminary trials using a white clover (Trifolium repens L.) understory to supply the nitrogen requirements of a cereal crop. Grass and Forage Science, 47, 366-374. http://dx.doi.org/10.1111/j.1365-2494.1992.tb02282.x

Jones, L., \& Clements, R. O. (1993). Development of a low input system for growing wheat (Triticum vulgare) in a permanent understory of white clover (Trifolium repens). Annals of Applied Biology, 123, 109-119. http://dx.doi.org/10.1111/j.1744-7348.1993.tb04078.x

Ladd, J. N., Amato, M., Jackson, R. B., \& Butler, J. H. A. (1983). Utilization by wheat crops of nitrogen from legume residues decomposing in soils in the field. Soil Biology and Biochemistry, 15, 231-238. http://dx.doi.org/10.1016/0038-0717(83)90064-0

Le Gouis, J., Beghin, D., Heumez, E., \& Pluchard, P. (2000). Genetic differences for nitrogen uptake and nitrogen utilisation efficiencies in winter wheat. European. Journal of Agronomy, 12, 163-173. http://dx.doi.org/10.1016/S1161-0301(00)00045-9

Martin, M. P. L. D., \& Snaydon, R. W. (1982). Intercropping barley and beans. 1. Effects of planting pattern. Experimental Agriculture, 18, 139-148. http://dx.doi.org/10.1017/S0014479700013612

Moll, R. H., Kamprath, E. J., \& Jackson, W. A. (1982). Analysis and interpretation of factors which contribute to efficiency of nitrogen utilization. Agronomy Journal, 74, 562-564. http://dx.doi.org/10.2134/agronj1982.00021962007400030037x

Ofori, F., \& Stern, W. R. (1987). Cereal-legume intercropping systems. Advances in Agronomy, 41, 41-90. http://dx.doi.org/10.1016/S0065-2113(08)60802-0

Olesen, J. E., Berntsen, J., Hansen, E. M., Petersen, B. M., \& Petersen, J. (2002). Crop nitrogen demand and canopy area expansion in winter wheat during vegetative growth. European Journal of Agronomy, 16, 279-294. http://dx.doi.org/10.1016/S1161-0301(01)00134-4 
Ortiz-Monasterio, J. I., Sayre, K. D., Rajaram, S., \& McMahon, M. (1997). Genetic progress in wheat yield and nitrogen use efficiency under four nitrogen rates. Crop Science, 37, 898-904. http://dx.doi.org/10.2135/cropsci1997.0011183X003700030033x

Pearman, I, Thomas, S. M., \& Thorne, G. N. (1978). Effect of nitrogen fertilizer on growth and yield of semi-dwarf and tall varieties of winter wheat. Journal of Agricultural Science, Cambridge, 91, 31-45. http://dx.doi.org/10.1017/S0021859600056604

Powlson, D. S., Pruden, G., Johnston, A. E., \& Jenkinson, D. S. (1986). The nitrogen cycle in the Broadbalk wheat experiment: recovery and losses of $15 \mathrm{~N}$ - labelled fertilizer applied in spring and inputs of nitrogen from the atmosphere. Journal of Agricultural Science, Cambridge, 107, 591-609. http://dx.doi.org/10.1017/S0021859600069768

Puckridge, D. W., \& Donald, C. M. (1967). Competition between wheat plants sown at a wide range of densities. Australian Journal of Agricultural Research, 18, 193-211. http://dx.doi.org/10.1071/AR9670193

Remsion, S. U. (1978). Neighbour effects between maize and cowpea at various levels of N and P. Experimental Agriculture, 14, 205-212. http://dx.doi.org/10.1017/S001447970000870X

Sarunaite, L., Kadziuliene, Z., \& Kadziulis, L. (2008) The impact of legumes on cereals in a crop rotation and legume-cereal bi-cropping. Biodiversity and animal feed: future challenges for grassland production. Proceedings of the 22nd General Meeting of the European Grassland Federation, Uppsala, Sweden, 9-12 June 2008. Grassland Science in Europe, 13, 625-627.

Schmidt, O., \& Curry, J. P. (1999). Effects of earthworms on biomass production, nitrogen allocation and nitrogen transfer in wheat-clover intercropping model systems. Plant and Soil, 214(1-2), 187-198. http://dx.doi.org/10.1023/A:1004723914623

Schmidt, O., Clements, R. O., \& Donaldson, G. (2003). Why do cereal-legume intercrops support large $\begin{array}{lllll}\text { earthworm } & \text { populations. } & \text { Applied Soil }\end{array}$ http://dx.doi.org/10.1016/S0929-1393(02)00131-2

Simpson, J. R. (1965). The transfer of nitrogen from pasture legumes to an associated grass under several systems of management in pot culture. Australian Journal of Agricultural Research, 16, 915-926. http://dx.doi.org/10.1071/AR9650915

Sowers, K. E., Pan, W. L., Miller, B. C., \& Smith, J. L. (1994). Nitrogen use efficiency of split nitrogen applications in soft white winter wheat. Agronomy Journal, 86, 942-948. http://dx.doi.org/10.2134/agronj1994.00021962008600060004x

Spiertz, J. H. J., \& Ellen, J. (1978). Effects of nitrogen on crop development and grain growth of winter wheat in relation to assimilation and utilization of assimilates and nutrients. Netherlands Journal of Agricultural Science, 26, 210-231.

Stewart, R. H., Lynch, K. W., \& White, E. M. (1980). The effect of growing clover cultivars in association with barley cultivars upon grain yield of the barley crop in the year of sowing and the subsequent year. Journal of Agricultural Science, Cambridge, 95, 715-720. http://dx.doi.org/10.1017/S0021859600088110

Thorsted, M. D., Olesen, J. E., \& Koefoed. (2002). Effects of white clover cultivars on biomass and yield in oat/clover intercrops. Journal of Agricultural Science, Cambridge, 138, 261-267. http://dx.doi.org/10.1017/s0021859602002010

Thorsted, M. D., Olesen, J. E., \& Weiner, J. (2006a). Width of wheat rows and clover strips influence grain yield in winter wheat/white clover intercropping. Field Crops Research, 95, 280-290. http://dx.doi.org/10.1016/j.fcr.2005.04.001

Thorsted, M. D., Weiner, J., \& Olesen, J. E. (2006b). Above- and below-ground competition between intercropped winter wheat Triticum aestivum and white clover Trifolium repens. Journal of Applied Ecology, 43, 237-245. http://dx.doi.org/10.1111/j.1365-2664.2006.01131.x

Thorsted, M. D., Olsen, J. E., \& Weiner, J. (2006c). Mechanical control of clover improves nitrogen supply and growth of wheat in winter wheat/white clover intercropping. European Journal of Agronomy, 24, 149-155. http://dx.doi.org/10.1016/j.eja.2005.07.004

White, J. G., \& Scot, T. W. (1991). Effects of perennial forage-legume living mulches on no-till winter wheat and rye. Field Crops Research, 28, 135-148. http://dx.doi.org/10.1016/0378-4290(91)90079-B 
Whitney, A.S. (1977). Contribution of forage legumes to the nitrogen economy of mixed swards. A review of relevant research. In: Ayanaba, A., Dart, P.J. (Eds.), Biological nitrogen fixation in farming systems in the tropics, 89-114. John Wiley, New York.

Williams, E. D., \& Hayes, E. D. (1991). Growing spring cereals in a white clover (Trifolium repens) crop. Journal of Agricultural Science, Cambridge, 117, 23-37. http://dx.doi.org/10.1017/S002185960007893X

Wilson, B. J., Moss, S. R., \& Wright, K. J. (1989). Long term studies of weed populations in winter wheat as affected by straw disposal, tillage and herbicide use. Proceedings, Brighton Crop Protection Conference-Weeds, 1989 BCPC Publications, Croydon, UK, pp3A-6, 131-136.

\section{Copyrights}

Copyright for this article is retained by the author(s), with first publication rights granted to the journal.

This is an open-access article distributed under the terms and conditions of the Creative Commons Attribution license (http://creativecommons.org/licenses/by/3.0/). 